\title{
НАСТАВНО ТУМАЧЕЊЕ ДРАМЕ КРАЉ ВУКАШИН ДРАГУТИНА ИЛИЋА
}

АПСТРАКТ: Многобројна драмска остварења Драгутина Илића, са методичког становишта, могла би се посматрати као естетски релевантна у наставном проучавању. Предмет истраживања овог рада јесте анализа историјске драме Драгутина Илића под називом Краљ Вукашин. У раду се дају прецизно осмишљени и конкретни методички кораци за наставно тумачење литерарног остварења Драгутина Илића. Драгутин Илић је успоставио оштар контраст између Вукашинових и Урошевих карактерних особина и животних ставова, што ће на репрезентативним примерима и бити показано. Акценат је стављен на драмска сукобљавања, као и на психолошки подтекст акција и реакција драмских ликова. Посебна истраживачка пажња усмерена је на сагледавање основних карактерних особина епског, историјског и драмског лика краља Вукашина Мрњавчевића.

Кључне речи: историјска драма, цар Урош, краљ Вукашин, круна, жена.

\section{TEACHING INTERPRETATION OF THE DRAMA KING VUKAŠIN WRITTEN BY DRAGUTIN ILIĆ}

ABSTRACT: It is an undisputable fact that, from a methodical perspective, many of the dramas written by Dragutin Ilić could be observed as aestethicaly relevant in the teaching process. The subject of this paper is the analysis of the historical drama King Vukašin written by Dragutin Ilić. Concrete and precisely designed methodical steps for a teaching interpretation of this literary piece are given in this paper. Ilić's sharp contrast between Vukašin's and Uroš's character traits and life philosophy will be shown on representative examples. Dramatic conflicts and a psychological subtext of the actions and reactions of the drama characters are highlighted. Special research attention is devoted to the epic, historical and drama characteristics of the king Vukašin Mrnjavčević.

Key words: historical drama, emperor Uroš, king Vukašin, crown, woman.

\section{1. УВОД}

Драгутин Илић је својим литерарним стваралаштвом несумњиво задужио српску књижевност. Писац је који је у српску књижевност „унео различите новине, а потом дуго остао неадекватно проучаван и вреднован” (Томић 2015: 105). Бавећи се романескним опусом Драгутина Илића, Ераковић је скренуо пажњу у којој мери је његов литерарни опус неправедно „егзистирао на маргинама српске књижевности попут изоловане појаве 
(овакав статус су веома дуго 'уживали' аутори попут Ђорђа Марковића Кодера и Пере Тодоровића)” (Ераковић 2004: 20)‥ Стваралаштво Драгутина Илића доиста је веома обимно и разноврсно, али лако је запазити да у његовом опусу преовлађују драме. Реља 3. Поповић вели да се највише истиче:

„књижевна делатност Драгутинова на драмском пољу. На тој је страни он имао најјачих и највиднијих успеха у свом књижевном раду. Ма колико да је доцније имао лепих и заслужених успеха и у лепој књижевности у прози, и то својим светлим сликама, а нарочито романима Хаци-Ђером и Хаџи-Дишом, ипак сви ти радови нису му прибавили онолико угледа, ни стекли онолико једнодушног признања колико је добио својим првим драмама Вукашином и Јаквинтом" (Поповић 1931: 21).

Овом приликом важно је истаћи да се драма Драгутина Илића под називом После милијон година ${ }^{2}$ издваја по многим карактеристикама и заузима значајно место у нашој књижевности, међутим, готово је у потпуности предана забораву. Наиме, драма После милијон година прва је, права, научнофантастична драма у свету (в. The Encyclopedia of Science Fiction, 2018). Драгутин Илић је засигурно писац који је кренуо путем којим су ишли Лаза Костић и Ђура Јакшић, „значајан и занимљив драмски песник, свакако централна личност наше драматургије у последње две деценије деветнаестог века" (Фрајнд 1987: 6). Фрајнд с разлогом додаје да се у појединим Илићевим драмама, нарочито у оним на прелазу из деветнаестог у двадесети век, примећују „квалитети који га чине необично блиским извесним тенденцијама у европском театру онога доба" (Фрајнд 1987: 6).

Многобројне Илићеве драме, са методичког становишта, могле би се посматрати као естетски релевантне у наставном проучавању. Стога пример наставног проучавања драме Краљ Вукашин представља допринос и покушај увођења литерарног стваралаштва Драгутина Илића у наставни процес.

1 Неправда је посебно чињена према плодном драмском стваралаштву „Драгутина Илића (чијих је дванаест позоришних комада играно на сцени београдског Народног позоришта, а четири у Новом Саду), а који је као песник остао у сенци свог млађег брата Војислава, па је данас махом познат као писац историјских романа" (Михаиловић 1981: 104). За реафирмацију овог литерарног ствараоца заслужни су многи проучаваоци: Божо Вукадиновић, Душан Иванић, Предраг Палавестра, Марта Фрајнд, Сава Дамјанов, Гаврило Ковијанић, Бојана Стојановић Пантовић, Радослав Ераковић, Владимир Гвозден и др. (в. Гвозден 2015: 7-9).

2 Драма После милиЈон година [sic], објављена је 1889. године у часопису Коло. „ТВ адаптацију фрагмената из ове драме 1973. године приказао је редитељ Јелашин Синовец" (Михаиловић 1981: 105). После милијон година једина је Илићева драма која је у новије време (1995) доживела извођења у Народном позоришту у Београду (в. Фрајнд 1996: 168). 
Пре наставне интерпретације Илићеве драме Краљ Вукашин неопходно је мотивисати ученике за пријем текста.

„Успех у проучавању уметничког текста првенствено зависи од тога како је он прочитан, колико се читалац у њега емоционално, мисаоно и фантазијски уносио, шта је помоћу њега доживео, наслутио и сазнао. Самим тим благовремено и умесно подстицање ученика на доживљајно и истраживачко читање постаје пресудна и далекосежна наставна делатност. Познато је да се ученици који су претходно мотивисани за читање и слушање књижевног дела дубље и свестраније уносе у његов свет и сазнају о њему знатно више од ђака који су на том пољу остали без посебног подстицања" (Николић 2012: 259).

Како је реч о наставном проучавању историјске драме, корелација са историјским подацима може представљати добру мотивацију за читање драме (в. Туцаковић 2016: 40, 41). Један од начина за мотивисање ученика на доживљајно и истраживачко читање поменуте драме, могло би да буде представљање историјског, али и епског портрета краља Вукашина, што би ученицима значајно олакшало разумевање Илићеве драме. Како су се ученици још у основној школи сусретали са историјским и епским ликом Вукашина Мрњавчевића, било би пожељно да они самостално ураде овај задатак. Задатак наставника огледа се само у његовим брижљивим настојањима да из многобројне и разнолике литературе, која осликава историјски и епски лик краља Вукашина, ученике упути на оне податке који су најважнији за наставно тумачење драме Краљ Вукашин. Када је реч о историјској литератури, ученицима би од користи могле да буду књиге Крај српског царства Радета Михаљчића (поглавље: Савладарство - надмоћ обласних господара, стр. 93-111) и Серска област после Душанове смрти Георгија Острогорског (поглавље: Велики рат против Турака. Припреме и последице, 127-147). Наставник би свакако могао ученицима који су задужени за овај задатак да обезбеди скенирана поглавља наведених књига. С обзиром да је важно сагледати епски лик краља Вукашина, наставник ученике упућује да се подсете и прочитају следеће епске песме: Женидба краља Вукашина, Зидање Скадра, Урош и Мрњавчевић, Смрт иара Уроша. На делу часа који је предвиђен за мотивацију за читање, ученици коју су задужени за расветљавање историјског и епског лика краља Вукашина осталим ученицима ће представити резултате истраживања до којих су дошли. Наставник ће по потреби допуњавати и кориговати њихова излагања.

Када је реч о историјском лику Вукашина Мрњавчевића, ученици би требало да истакну да је у периоду владавине цара Уроша дошло до слабљења централне власти и уздизања српских моћних феудалаца. У времену распада Царства, Војислав Војиновић је био један од најмоћнијих, а пред крај живота и најмоћнији великаш у српској држави, моћнији чак и од самог Вукашина, будућег српског краља. Након његове смрти, водећу улогу у српској држави 
преузимају Вукашин Мрњавчевић и његов брат Угљеша, који постају најмоћнији обласни господари. Према Орбину, Вукашин и Угљеша (Орбин помиње и Гојка) били су синови сиромашног властелина Мрњаве из Ливна, кога је заједно са синовима Душан позвао на двор и 'много уздигао'. Угљеша је око 1346. године кратко управљао у околини Дубровника, као намесник Требиња, док се Вукашин у марту 1350. године помиње као жупан Прилепа (в. Михаљчић 1989: 93-111). Године 1365. Вукашин Мрњавчевић је крунисан за краља и савладара Урошевог, а његов брат Угљеша постаје деспот серске области којом је раније владала царица Јелена. Ученици би требало да нагласе да Вукашина, српског краља, народно предање памти као похлепног великаша, узурпатора и подмуклог убицу, те да је неоправдано негативна слика о Мрњавчевићу у српској историографији трајала веома дуго. Вукашин, дакле, није насилно присвојио власт, већ је уз царев пристанак и благослов краљице Јелене крунисан за краља (в. Михаљчић 1989: 93-111). Након Вукашиновог крунисања за краља, између њега и цара Уроша успостављен је однос савладарства са свим његовим карактеристикама које указују и на њихове добре односе - заједничко отпремање посланства, затим новац који цар и краљ заједно кују, сачувани су и примерци Вукашиновог новца кованог у ковници цара Уроша са натписом „Уросиус император” на једној и „краљ” на другој страни. Њихов савладарски однос потврђују и заједнички портрети на северном зиду цркве Светог Николе у манастиру Псачи, задужбини севастократора Влатка (в. Острогорски 1965: 10-12).

C обзиром да је Маричка битка тематски повезана са драмом Драгутина Илића, било би добро истаћи да је Вукашин Мрњавчевић учествовао у боју против Турака. Наиме, учестале навале Турака претиле су свим балканским државама, а Вукашинов брат, деспот Угљеша, мислио је само о томе како да заустави Муратово напредовање. Ове ставове делио је и његов брат Вукашин, уједно и једини Угљешин савезник. Вукашин и Угљеша кренули су на султанову престоницу. До битке је дошло 26. септембра 1371. године и то је био: „изненадан и потпуни слом смелог подухвата серског деспота и српског краља, погибија и једног и другог, две најјаче личности на тадашњем Балкану, пропаст њихове војске" (в. Острогорски 1965: 128-143). Мрњавчевићи су доживели слом на Марици 26. септембра 1371, а цар Урош је умро почетком децембра исте године, што је оповргло тезу по којој је Вукашин могао убити цара Уроша.

У народној књижевности ,постојаност титуле Вукашина Мрњавчевића (краљ) не подразумева његову (историјску) легитимну владарску позицију, већ га обележава као узурпатора" (Самарџија 2008: 206). Овај концепт се примењује и у српској историјској драми, те се Вукашин у драмама појављује као узурпатор царске круне. Ученици који су имали задатак да представе епски лик краља Вукашина подвлаче да је у епској поезији Вукашин често бивао осликаван као главни непријатељ цара Уроша, цара који је у епској поезији означаван као „дете, нејак царевић Урош” (СНП, Вук, II, 34), дете „у 
кол'јевци од четрест дана" (СНП, Вук, II, 33). У песми Урош и Мрњавчевићи (СНП, Вук, II, 34) Вукашин, заједно са својом браћом, осликан је као крвожедни и похлепни отимач Урошевог царства. Вукашиново властољубље своју кулминацију досеже у оним тренуцима када потеже нож на свога сина Марка. У песми Женидба краља Вукашина (СНП, Вук, II, 25) Вукашину се наново приписују негативне карактеристике. Он наводи Видосаву, Момчилову љубу, да свог мужа, чувеног јунака, изда. У песми Зидање Скадра (СНП, Вук, II, 26) „краљ Вукашин вјеру погазио,/ Те он први својој љуби каза:/ Да се чуваш, моја вјерна љубо!/ Немој сјутра на Бојану доћи/ Ни донијет' ручак мајсторима,/ Јер ћеш своју изгубити главу”, док је у песми Смрт иара Уроша (СНП, Вук, VI, 25), Вукашин представљен као Урошев убица: „Отрова га и сарани млада”.

Било би корисно да ученичко представљање историјског и епског лика краља Вукашина прате звуци средњовековне музике, као и репрезентативна ликовна остварења и илустрације: портрети цара Душана и краља Уроша са лозе Немањића из манастира Дечани, слика распада Душановог царства, портрети цара Уроша и краља Вукашина из манастирске цркве у Псачи, портрет краља Вукашина из манастира Св. Арханђела код Прилепа, потпис цара Уроша и потпис краља Вукашина, илустрација новца који су ковали цар Урош и краљ Вукашин, печат краља Вукашина и слично. Оваква корелација са музичком и ликовном уметношћу ${ }^{3}$ свакако би представљала ваљану мотивацију за рад на самом тексту, нарочито ако се „представи у интермедијалној презентацији, као делотворни принцип очигледности” (Јакшић Провчи 2017: 143).

\section{3. ПРИПРЕМНИ ЗАДАЦИ}

Подстакнути причом о историјском и епском лику краља Вукашина, ученици су мотивисани да проуче и његов драмски лик. Након успешне мотивације, уследиће доживљајно и истраживачко читање. Међутим, пре него

\footnotetext{
3 „Корелацијско-интеграцијски приступи и поступци могу бити ужи (унутар градива истог предмета) и шири, ако се повезују знања или наставне теме различитих предмета или васпитно-образовних области. Тиме се тема захвата комплексно и свестрано и ученици је боље могу разумети. На пример, када се теме из нашег предмета корелирају са ликовном, музичком, сценском или филмском уметношћу или са сродним друштвеним предметима” (Петровачки 2008: 170). „Сва подручја умјетности у настави пред заједничким су задацима: развити трајан интерес и љубав према умјетности, изградити укус и критерије у просуђивању и оцјењивању умјетничких дјела, формирати поглед на свијет у којем хуманистичка и стваралачка компонента заузимају средишње мјесто, одгојити културне посјетиоце концерата, изложби, галерија, казалишних представа, активне читаоце књижевних дјела" (Rosandić 1988: 187).
} 
што ученици приступе доживљајном и истраживачком читању, наставник би требало да формулише квалитетне и инспиративне припремне задатке, који ће ученике оспособити за активно учешће на часовима који су предвиђени за наставно проучавање драме. Наиме, наставник мора водити рачуна о припремљености ученика за целовиту анализу књижевног дела. Давање тих задатака јавља се, како казује Павле Илић:

„као део систематског ученичког мотивисања и самосталног рада на изучавању књижевног књижевног дела. На тај начин његово ангажовање у припремању за час резултат је укупног деловања даље дугорочније $u$ непосредно-тренутне мотиващије за тај рад” (Илић 2006: 212).

Ученицима наставник даје следеће припремне задатке:

- $\quad$ Припремите се да говорите о одлуци коју доноси Сабор.

- Спремите се да казујете о ликовима који се залажу за одузимање Вукашиновог намесништва и о ликовима који су Вукашинове присталице.

- Подвуците кључна места у тексту која указују на карактерне особине драмских ликова. Размишљајте о психолошком подтексту њихових акција и реакција.

- Означите ситуације и догађаје које сматрате важним за развој драмске радње, а нарочито обратите пажњу на драмске сукобе.

- $\quad$ Маркирајте у тексту места у којима запажате шта све Вукашин и Влатко Грчић чине како би остварили своје намере. У дневник читања забележите ко су Вукашинове и Грчићеве жртве, као и последице њихових поступака.

\section{4. ПРЕДМЕТ СУКОБА}

Ученици су првим припремним задатком наведени да самостално одреде предмет сукоба Илићеве драме. Као што истиче Бранка Јакшић Провчи:

„Извориште конфликтних ситуација разуђено је колико и драмска тематика; то могу бити различити погледи на свет, супротни ставови, мишљења, идеје, поводи се налазе у људској злоби, охолости, лудости, те у предрасудама, различитим интересима, развијеним амбицијама где сам човек сам себи може бити препрека, сукоб с важећим друштвеним законима и прихваћеним конвенцијама, на крају, судбина или фаталност. Но, сви ови поводи, само су почетна ситуација за даље развијање драмских ситуација и њихову унутрашњу мотивацију” (Јакшић Провчи 2009: 237). 
Оно што иницира драмски сукоб ${ }^{4}$ у Илићевом делу јесу злоба, охолост и славољубље Вукашина Мрњавчевића, незасита, опсесивна жеља за круном, а предмет сукоба је, дакле, круна. Након што установе шта је предмет сукоба ове драме, ученици одређују време радње - 14. век, и истичу да се радња драме дешава у цркви Светих Архангела, на двору Урошевом, двору Вукашиновом, двору Лазаревом, планини Некудумље и на реци Марици.

\section{5. ПИТАҢЕ ВУКАШИНОВОГ НАМЕСНИШТВА}

Први чин драме Краљ Вукашин почиње сценом која описује атмосферу на двору цара Уроша. Драму Краљь Вукашин отварају ликови који су одређени као Урошеви заштитници. Они ишчекују Сабор на којем би требало донети кључне одлуке о владавини цара Уроша и намесништву краља Вукашина. Након што ће Драшко, Јелена, Јелисавета и Лазар констатовати да је Вукашин главна претња за цара Уроша и амбициозни узурпатор, на сцени се појављује мноштво ликова који би требало да одлуче о судбини Вукашиновог намесништва. Насупрот Драшку и Лазару који ревносно штите круну Урошеву и инсистирају да се Вукашину одузме намесништво које му већ седам година не припада, стоје Вукашинова браћа Угљеша и Гојко који беспоговорно извршавају сваку Вукашинову наредбу, те лажима и сплеткама покушавају да му сачувају леђа. Мрњавчевићи су жељни власти и моћи, а овакве ставове дели и властелин Алтоман. У овим тренуцима је на сцени, иако скривен иза стуба, и манипулатор Влатко Грчић, који пажљиво ослушкује о чему се казује на Сабору. Он је такође Вукашинов присталица, но, његове амбиције нису усмерене ка власти. Грчић стреми ка освајању срца царице Јелисавете. Патријарх Сава, главни представник закона, доноси одлуку по којој се Вукашину мора одузети намесништво, чиме се заправо зачиње основна конфликтна линија између Уроша и Вукашина:
„На царевој сам се смрти затек’о,
Вукашина је тада дозвао,
Намесничко му право предао:
До пунолетства младог Уроша
Нека му буде од помоћи тек.
Цар Урош онда беше врло млад.

\footnotetext{
${ }^{4}$ Према Лукачу, најважнији захтеви драме, које би писац требало да има на уму, приликом остваривања правог драмског конфликта су следећи: сукоб мора бити у вези са егзистенцијалним проблемом јунака који ће бити суштински за његов живот, а отуда и за публику; конфликт треба својим обликом да представи живот у целини, да целокупном својом снагом и многострукошћу захвата остави утисак о изразу целовитости неког живота; јунак који је у средишту драмског сукоба треба да буде репрезент типа човека којега оличава. Његова величина мора да буде апсолутна у односу на друге јунаке истог типа (в. Несторовић 2004: 414).
} 
Седам година прохујаше сад,

Цар је пунолетан, њему не треба

Вукашинове више потпоре

Државној цељи да га поведе.

Вукашине доста си владао!” (Илић 1987: 42).

Јасно се види да су ликови из поменуте сцене подељени у две оштро супротстављене групе. Једна група инсистира на уклањању Вукашина с престола, док друга група жели да Вукашин остане на власти. Чињеница је да ce:

„драмски ликови увек посматрају у релацији према другим ликовима, они не представљају развијене и литерарно нијансиране јунаке, већ носе само неколико карактерних црта које се представљају говореном радњом у њиховим међуодносима” (Јакшић Провчи 2017: 212)

„Постављањем лица у међусобне релације избегава се дијахронијско праћење радње” (Јакшић Провчи 2009: 246). Како би се избегло препричавање сцене у којој се разматра судбина Вукашиновог савладарства, од ученика се може затражити да разврстају ове ликове у две групе и да коментаришу њихове поступке, ставове и мишљења. Принцип поделе ликова заснивао би се на њиховим ставовима у вези са Вукашиновим намесништвом. Прва колона се односи на актере који се залажу за одузимање Вукашиновог намесништва, на Урошеве присталице, док другу групу чине лица која подржавају Вукашина. Ученици праве поделу јунака, а потом аргументују начин поделе адекватним примерима из текста.

ОДЛУЧИВАЮЕ О ВУКАШИНОВОМ НАМЕСНИШТВУ

\begin{tabular}{lr}
\hline ПРОТИВ ВУКАШИНА & ЗА ВУКАШИНА \\
\hline ДРАШКО БАТРИЋ & АЛТОМАН \\
\hline ЦАРИЦА ЈЕЛИСАВЕТА & УГЉЕША \\
\hline ЦАРИЦА ЈЕЛЕНА & ГОЈКО \\
\hline КНЕЗ ЛАЗАР & ВЛАТКО ГРЧИЋ \\
\hline ПАТРИЈАРХ САВА \\
\hline
\end{tabular}

Од оног тренутка када Сабор одузме Вукашину намесништво, он ће сву своју енергију усмерити ка деструкцији законитог владара. Стога би у даљој наставној анализи посебну пажњу требало посветити Вукашиновој реакцији која је уследила након одузимања намесништва.

\section{6. ВУКАШИН И УРОШ КАО АНТИПОДИ}

Следећи самостални ученички задатак односи се на представљање Вукашиновог и Урошевог лика. Ученике је потребно упутити да у дневнику читања пронађу места која се односе на расветљавање њихових ликова. „У методичком приступу интерпретацији лика, могуће је организирати наставни 
рад који се темељи на начелу успоредбене анализе ликова" (Diklić 1978: 256). Овакав приступ је несумњиво најподеснији за тумачења Вукашиновог и Урошевог лика. Ученици усмеравају своју пажњу на њихове поступке, понашања, етичка својства, психичке одлике. Решавањем овог задатка ученици ће самостално запазити колико су заправо дијаметрално супротни њихови ликови. Лако ће ученици уочити да је Драгутин Илић успоставио оштар контраст између Вукашинових и Урошевих карактерних особина и животних ставова. И пре него што су се Вукашин и Урош појавили на сцени писац је веома ефектно осликао њихове основне особине. Краљ Вукашин, негативни је јунак, покретач драмске радње, приказује се као аморалан човек опседнут влашћу. Карактерне особине које би могле да се припишу Вукашину су насилништво, подлост, похлепност и свирепост. Своје демонске планове правда чињеницом да је Урош недостојан носилац царске круне и да је недорастао владалачком позиву:

„На узвишеном српском престолу

Да гледам дете слабо, нејако,

Како га лажу, подло варају

А он им мирним срцем верује?

То не сме бити, не сме, вере ми!

Боље и њему нека буде крај,

Него ли земљи да помркне сјај,

Коју му даше силни дедови!” (Илић 1987: 62).

Вукашин је славољубив, безобзиран, суров, крут, спреман је да пролива крв зарад остваривања својих амбиција, „препреден ђаво, злобни сотона" (Илић 1987: 107). Међутим, важно је истаћи да се Вукашин исто тако показује и као веома храбар, одлучан, моћан и уман ратник.

С друге стране, за разлику од Вукашина, који је динамичан лик, стоји Урош који је статички конципиран. Урош је „благ, безазлен, миран, срца доброга” (Илић 1987: 37), „мирно јагње, мирни голуб” (Илић 1987: 66). Чак су и његове присталице свесне да Урош није кадар да сачува царство које је његов отац мукотрпним борбама сковао. Насилништво и агресија су појмови који су Урошу несхватљиви:

„Пре бих се своје круно одрек’о

Него ли вашу крвцу пролио!

Скупа је круна, то ја добро знам,

За коју сте се славно борили;

Ма скупљи ј' пехар, скупљи дворови,

У којим људска крвца борави!

(...)

Да га ослепим?

За љубав круне сјаја варљивог?

Та ја се грозим таквог помисла!

Нашто ми онда круну носити?

То нећу! 
Ја ћу се одрећи мога престола,

Ако се тако само царује.

Не могу л’ владат ко што влада цар,

Ко зликовац нећу никада!" (Илић 1987: 43, 60).

За разлику од мирољубивог Уроша који поседује идеалистичко поимање о владавини, Вукашин је немилосрдан:

„Ја хоћу да владам - руком гвозденом:

Самовољне ћу стегнут војводе,

И тешко томе, ко ми пречит сме!

У пак’о ћу га мрачни послати!” (Илић 1987: 62).

Урош је праведан, честит, лојалан, али и исувише покоран, колебљив, неискусан и лаковеран. Млади цар не поседује снагу да се одупре крвожедном Вукашину и да сачува наслеђену круну ${ }^{5}$. Чак и када донесе одлуку да подигне мач, покорност и лаковерност ће га спутати у борби.

\section{7. ВУКАШИН И ВЛАТКО}

Након констатације да су два главна лика заправо два антипода, од ученика се може затражити да издвоје драмског актера који је најсличнији Вукашину и да образложе свој одговор. Запазиће ученици да је реч о Влатку Грчићу, те да се све Вукашинове карактерне особине могу приписати и овом лику (сем храбрости и ратничких вештина). Оно што повезује ова два лика јесте њихова опсесивна жеља за уништењем цара Уроша. Вукашин је опседнут Урошевом круном, а Грчић Урошевом женом.

Једно од доминантних питања које отвара ова драма јесте следеће: На које начине Вукашин и Грчић стреме остваривању својих циљева? Пут ка остваривању њихових циљева доводи до немилих догађаја из којих се рађају многобројне жртве. У вези са изреченим, следећи задатак за ученике јесте, да уз помоћ дневника читања истакну места у тексту која јасно показују шта су све Влатко Грчић и Вукашин учинили не би ли се домогли својих циљева, и ко су њихове жртве. Наставник ученике може поделити у две групе. Прва

\footnotetext{
${ }^{5}$ Његов најбољи пријатељ и заштитник је свестан тешког положаја у коме се Урош налази:

„Јадни Уроше!

За Божијега створен си анђела,

Анђели те земљи послаше

Да љубав сејеш међу људима.

Ма људи нису за то створени, За љубав нису љути тигрови,

Међ њима ћеш јадно пропасти” (Илић 1987: 61).
} 
група би тумачила Грчићеве поступке и поступке његових помоћника, наспрам поступака његових жртава и њихових помоћника, а друга група би исти принцип требало да примени на случају „Вукашин и његове жртве”.

Први тренутак у ком долази до акције Урошевог непријатеља Влатка Грчића јесте покушај атентата на цара. Ученици треба да истакну ко је иницијатор атентата, чиме је овај злочин мотивисан, а потом своју пажњу усмеравају ка расветљавању Боривојеве улоге у овој сцени и врлинама које украшавају његов лик. Ученицима неће бити тешко да запазе да је иницијатор атентата на Уроша био Влатко Грчић. Међутим, не сме се занемарити чињеница да је управо Вукашин био организатор овог гнусног чина. Покушај убиства младог цара уследио је одмах након одлуке Сабора, који Вукашину одузима намесништво. Влатко Грчић се према Вукашиновим упутствима обраћа Нестору, коме за извршавање овог злочина обећава велику суму новца. Ученици ће такође констатовати да је Урошев живот спасен захваљујући његовој мајци. Царица Јелена, знајући да је Урош сам и без заштите отишао на гроб свога оца Душана, шаље оданог Боривоја, који се обрачунава са Нестором и спасава Уроша. Тако Вукашинови и Грчићеви планови бивају осујећени. Боривоје отвара Урошу очи и успева да га увери у опасност која се надвила над српским двором, а Урош, вођен Боривојевим саветима, одлази у Крушевац на двор кнеза Лазара.

Други демонски потез Влатка Грчића био је напад на царицу Јелисавету. Када одреде главне учеснике овог догађаја, ученици ће се позабавити односом између Грчића и Јелисавете. Важно је обратити пажњу на места у којима се уочава на који начин Грчић види Јелисавету, шта она за њега представља, али и на она места која осликавају Јелисаветине реакције на Грчићева удварања. Ученици би требало да прокоментаришу улогу Боривојевог појављивања у овој сцени. Са лакоћом ће ученици установити да заљубљени Влатко Грчић све своје снаге усмерава ка освајању срца царице Јелисавете. Обожавана Јелисавета постаје Влаткова опсесија. Он непрестано снива о недостижној љубави и смишља на који начин би могао да разори царски брак. Влаткови планови су неоствариви, јер Јелисаветину љубав и брижност ништа није могло да поколеба. Његови изливи нежности и изјава љубави Јелисавету згрожавају и она са гнушањем га одбија. Међутим, насилник Влатко ће силом покушати да освоји младу царицу. У том тренутку се на сцени појављује анђео чувар царског пара, Боривоје, који Јелисавету избавља из руку злочинца.

Ученици који припадају првој групи детаљно анализирају и узрок који је урушио добре односе између Уроша и његове жене, као и односе између Уроша и његовог најбољег пријатеља Боривоја. Наиме, Јелисавета, идеализован лик, несумњиво је верна жена која гаји искрене емоције према вољеном супругу. Исто тако, ученици су се у више наврата уверили у Боривојеву беспоговорну оданост. Међутим, злокобни Влатко Грчић, опседнут само једним - како раздвојити царски пар, подметнуће лажно писмо које Уроша уверава у 
Јелисаветину и Боривојеву издају. Подметнуто писмо, у коме се открива наводна Јелисаветина превара коју је починила са Боривојем, Уроша наводи да се сукоби са истинским заштитницима. Губи веру у љубав и не само да без доказа о превари одлучује да оконча брак, Урош прекида и пријатељство са Боривојем.

Када Вукашин дозна да је цар Урош безбедност и уточиште пронашао у Крушевцу, устремиће се на царицу Јелену и кнеза Лазара, са жељом да придобије њихово поверење и тако себи утаба пут ка цару. Стога би припадници друге групе требало, да као један од Вукашинових начина да се домогне круне, издвоје његова настојања да изманипулише бићем царице Јелене и кнеза Лазара. Ученици тумаче Вукашинове подмукле потезе којима покушава да обмане Лазара и Јелену, а затим образлажу њихове реакције. У жељи да увери кнеза Лазара у своје доброчинство, Вукашин Лазару шаље писмо пуно лепих и милосрдних речи, у које кнез неће поверовати. С друге стране, иако се на почетку Вукашиновог дијалога са Јеленом, она учинила као неустрашиви противник злокобног узурпатора, Вукашин ипак успева да је насамари. Уверава је у исправност својих намера и наводи је да почини кобну грешку, грешку која њеног сина одводи у смрт. Лукави и ласкави Вукашин се најпре позива на Душанову одлуку, гарант његове оданости, а потом покушава да заведе царицу Јелену. Ученици су већ констатовали да је Јелисавета с гнушањем одбијала Грчићева удварања, стога је пожељно сагледати како се Јелена понаша у моментима у којима јој Вукашин изјављује љубав.

Пошто су ученици успешно растумачили Вукашинов и Јеленин однос, своју истраживачку пажњу посвећују: разлозима Урошевог повратка у Призрен - у канџе свог највећег непријатеља, ликовима који су допринели Урошевом повратку и ликовима који су исти покушали да спрече. Ученици ће закључити да лаковерна Јелена, вођена Вукашиновим инструкцијама, након извесног времена клетвом наређује Урошу да се врати у Призрен. Од Вукашиновог оштрог противника она се претвара у његовог помоћника. Шаље сину писмо у коме га заклиње да се врати. Урош тада, заједно са Јелисаветом, доноси одлуку која ће га коштати живота - враћа веру у свог највећег непријатеља. Рашка властела на челу са кнезом Лазаром, на све могуће начине покушава да уруши идеалистичку представу коју Јелена пласира о Вукашину и моли Уроша да се не враћа у Призрен. Урош, међутим, није одустао од своје одлуке. Добивши Јеленино писмо у коме му мајка казује да се врати, Урош је помислио: „Ком’ да верујем, ако мајци не" (Илић 1987: 77), а при томе, застрашен мајчином клетвом, напушта место које му је гарантовало безбедност.

Ученицима ће највећу пажњу несумњиво привући мотив смрти, један од доминантних мотива драме Краљь Вукашин. Вукашин као наручилац и Влатко Грчић као извршилац његове наредбе убијају Уроша. Ученици увиђају да ова два актера своје снаге удружују само у оним тренуцима у којима планирају убиство цара Уроша (1. неуспели атентат на цара Уроша; 2. убиство цара Уроша). Са планине Некодумље се Урош никада неће вратити. На 
Вукашинов знак, Влатко одузима младом цару живот. Након овог немилог догађаја, ученици уочавају сцену поновног насилног покушаја освајања Јелисавете. Вукашинова издајничка природа кулминирала је оног момента када је саучеснику Влатку Грчићу, у страху да га не изда и открије сва његова недела, одузео живот. При томе, Вукашин је био сигуран да ће стећи царичино поверење уколико Влатка лиши живота.

Вукашин је на корак до остваривања својих демонских планова. Након тумачења драматичне сцене која приказује убиство цара Уроша и Влатка Грчића, ученици који припадају другој групи треба да истакну ко су Вукашинове нове жртве и којим средствима их уклања са двора. Ученици ће запазити да су након Урошевог нестанка наступили дани туге на двору. Иако је дубоко потресена, царица Јелисавета преузима престо. Од Гаврана и Арсојевића се сазнаје о њеним настојањима да склопи пакт са Грцима, који би требало да јој помогну у борби против Вукашина. Након што је уклонио Уроша, Вукашин ће уз помоћ Алтомана, Угљеше и Гојка, смислити кобни план, како да уклони Јелисавету и Јелену, али и њиховог беспоговорног помоћника Боривоја. Ослепљење Боривојево, оптуживање Јелисавете за превару, убиство Урошево и тровање грчких посланика, Вукашину је омогућило да се коначно домогне круне, због које је и стао на плочник злочина. У овој сцени је посебно важно размотрити улогу царице Јелене. Громогласно ће мајка Урошева проклињати Вукашина, а њена клетва ће очевидно утицати на трагичну Вукашинову судбину.

\section{1. Изглед табле, на крају презентовања ученичког рада}

СЛУЧАЈ ГРЧИЋ
ПОКУШАЈ АТЕНТАТА НА ЦАРА УРОША ВУКАШИН

ПОКУШАЈ АТЕНТАТА НА ЦАРА УРОША

Вукашин (организатор), Грчић (посредник), (помоћник Нестор) - Урош (помоћник Јелена, Боривоје)

\begin{tabular}{|c|c|}
\hline & $\begin{array}{l}\text { Манипулација кнеза Лазара и царице } \\
\text { Јелене } \\
\text { Вукашин - кнез Лазар } \\
\text { Вукашин - Јелена }\end{array}$ \\
\hline $\begin{array}{l}\text { Први напад на Јелисавету } \\
\text { Грчић - Јелисавета (помоћник Боривоје) }\end{array}$ & $\begin{array}{l}\text { Урошев повратак у Призрен } \\
\text { Вукашин (помоћник Јелена) - Урош } \\
\text { (помоћници Лазар, Боривоје, Трушко, } \\
\text { неименовани властелин) }\end{array}$ \\
\hline \multicolumn{2}{|l|}{$\begin{array}{l}\text { Подметање лажног писма } \\
\text { Грчић (помоћник Алтоман) - Урош, } \\
\text { Јелисавета, Боривоје }\end{array}$} \\
\hline \multicolumn{2}{|c|}{$\begin{array}{c}\text { УБИСТВО ЦАРА УРОША } \\
\text { Вукашин (организатор), Грчић (извршилац) - Урош }\end{array}$} \\
\hline $\begin{array}{l}\text { Други напад на Јелисавету } \\
\text { Грчић - Јелисавета (помоћник Вукашин) }\end{array}$ & $\begin{array}{l}\text { Убиство Влатка Грчића } \\
\text { Вукашин - Грчић }\end{array}$ \\
\hline & Ослепљење Боривоја \\
\hline
\end{tabular}


Вукашин (помоћник Гојко) - Боривоје

(помоћник Драшко)

Оптуживање Јелисавете

Вукашин (помоћници Алтоман, Угљеша)

- Јелисавета (Јелена)

Вукашин је, дакле, успешно уклонио све припаднике династије Немањића и ближи се остваривању свог циља:

„Дакле сам циљу своме стигао.

Под златном круном српске државе

Вукашинова глава борави!

Престо је празан, царска порфира

Скоро ће китит’ плећа краљева" (Илић 1987: 114).

\section{8. ПРЕОБРАЖАЈ КРАЉЕВОГ ЛИКА}

Вукашинове жртве, почевши од Уроша, до Јелисавете и Јелене уклоњене су са двора. Вукашинови крвнички поступци допринели су и томе да се један од најоданијих Урошевих присталица, Драшко Батрић, окрене исламу. Због Вукашина, тачније у замену са његову крв, Драшко постаје српски издајник. У сцени која казује о Маричкој бици се уочава Драшко и то на челу турске војске. Вукашин, узурпатор и убица, у овој сцени бива представљен као храбри борац против Турака. Вукашин јесте крвник и Урошев убица, но, Илић не пропушта прилику да проговори о Маричкој бици, у којој под вођством краља Вукашина: „тридесет хиљада Турака посласмо на онај свет. Тридесет хиљада изгибе, а што остаде побеже као без душе" (Илић 1987: 115). Као што Ераковић прецизно запажа:

„без обзира на карактер јунака који због гордости исказане у победи и поразу асоцира на ликове много познатијих узурпатора у српској књижевности 19. века, попут Његошевог Сатане у Лучи микрокозма, доследно инсистирање на одлучној борби против Турака нарушава представу о Вукашину као крвнику потпуно недужног Немањића" (Ераковић 2006: 95-96).

Штавише, када дође дуго ишчекивани моменат у коме би требало да преузме царску круну, Вукашин ће је одбити, сматрајући себе недостојним наследником Душана Силног. Чињеница је да је Драгутин Илић представио Вукашина као властољубивог узурпатора, који није презао од најгорих злочина. Међутим, Вукашин је делао и као храбри ратник, који се свим силама трудио да одбрани српску земљу.

Приликом говора о последњој сцени Илићеве драме, ученици би требало да се позабаве трансформацијама кроз које пролазе Драшко и Вукашин, дакако, поткрепљујући своје одговоре цитатима из текста. Драшко постаје српски издајник, а Вукашина свест о почињеним греховима доводи до 
освешћења. Када му се понуди царска круна, сматрајући себе недостојним наследником Душановог царства, одбиће је:

„... Овај терет, круну Србије,

Коју је славни Душан сковао,

На својој глави не смем носити! -

Тек такав јунак кад се појави,

Достојан сенке славног Душана,

Таквоме треба круну предати" (Илић 1987: 117).

Вукашинова свест о сопственим неделима није могла да допринесе промени његове судбине и амбициозни узурпатор постаје жртва властитих сплетки. Ваљало би подстицати ученике да коментаришу и промену којој подлеже Арсојевићев лик, једини лик који до краја драме није веровао у крволочну природу краља Вукашина. Када се увери у све злочине које је Вукашин починио, Арсојевић ће га усмртити. С његове одоре ће стргнути орла и узвикнути:

„Ово су знаци цара Уроша!

(...)

За ове груди нису сковане,

Достојнији ће га од сад носити" (Илић 1987: 127).

\section{9. ЗАКЉУЧАК}

Истраживачки задаци у раду су прецизно осмишљени, а ученици уз наставникове инструкције самостално одређују предмете сукоба, анализирају драмске сукобе, психолошки подтекст акција и реакција драмских јунака. Ученици истичу основне карактерне особине епског и историјског лика краља Вукашина Мрњавчевића и упоређују их са краљевим драмским ликом. На тај начин ученици увиђају да је Драгутин Илић, приликом обликовања главног јунака своје драме, користио народну поезију и легенде, али и аутентичне историјске податке. С једне стране, у драмском лику краља Вукашина, видљив је епски краљ - лукав, амбициозан, манипулативни узурпатор и убица цара Уроша, док се са друге стране уочавају његове ратничке и владарске способности, храброст и неустрашивост, што Илићевог јунака несумњиво приближива краљевом историјском лику.

\section{ИЗВОРИ}

Илић, Д. (1987). “Краљ Вукашин: историјска драма у пет чинова“, у Изабране драме. Драгутин Илић, ур. М. Фрајнд (Београд: Нолит): 33-128 [Ilić, D. (1987). "Kralj Vukašin: istorijska drama u pet činova“, u Izabrane drame. Dragutin Ilić, ur. M. Frajnd (Beograd: Nolit): 33-128]

Стефановић Караџић, В. (2006). Српске народне пјесме: скупио их Вук Стеф. Караџић. Приредила С. Самарџија. Београд: Завод за уџбенике и 
наставна средства [Stefanović Karadžić, V. (2006). Srpske narodne pjesme: skupio ih Vuk Stef. Karadžić. Priredila S. Samardžija. Beograd: Zavod za udžbenike i nastavna sredstva]

\section{ЛИТЕРАТУРА}

Diklić, Z. (1978). Književni lik u nastavi: metodičke osnove za interpretaciju književnog lika. Zagreb: Školska knjiga.

Ераковић, Р. (2004). Роман Драгутина Илића. Панчево: Мали Немо [Eraković, $\mathrm{R}$.

(2004). Roman Dragutina Ilića. Pančevo: Mali Nemo]

Ераковић, Радослав (2006). “Лик трагичног узурпатора у контексту европске традиције: краљ Вукашин Драгутина Илића“, у Транспозищија историјских догађаја и личности у трагедији код Словена (Ниш: Центар за научна истраживања САНУ и Универзитет у Нишу): 89-102 [Eraković, R. (2006). "Lik tragičnog uzurpatora u kontekstu evropske tradicije: kralj Vukašin Dragutina Ilića“, u Transpozicija istorijskih događaja u ličnosti u tragediji kod Slovena (Niš: Centar za naučna istraživanja SANU i Univerzitet u Nišu): 89-102]

Гвозден, В. (2015). “Велика тајна Драгутина Илић“, у Драгутин Илић, ур. В. Гвозден (Нови Сад: Издавачки центар Матице српске): 7-19 [Gvozden, V. (2015). "Velika tajna Dragutina Ilića“, u Dragutin Ilić, ur. V. Gvozden (Novi Sad: Izdavački centar Matice srpske): 7-19]

Илић, П. (2006). Српски језик и књижевност у наставној теорији и пракси: методика наставе. Нови Сад: Змај [Ilić, P. (2006). Srpski jezik $i$ književnost u nastavnoj teoriji i praksi: metodika nastave. Novi Sad: Zmaj]

Јакшић Провчи, Б. (2009). "Како приступити драмском делу“, у Тумачења књижевног дела и методика наставе. Део 2, ур. О. Радуловић (Нови Сад: Филозофски факултет, Одсек за српску књижевност и језик : Orpheus): 233-249 [Jakšić Provči, B. (2009). "Kako pristupiti dramskom delu“, u Tumačenja književnog dela i metodika nastave. Deo 2, ur. O. Radulović (Novi Sad: Filozofski fakultet, Odsek za srpsku književnost i jezik : Orpheus): 233-249]

Јакшић Провчи, Б. (2017). Текст у калеидоскопу. Нови Сад: Филозофски факултет [Jakšić Provči, B. (2017). Tekst u kaleidoskopu. Novi Sad: Filozofski fakultet]

Михаиловић, Д. (1981). “Три незавршена позоришна комада Драгутина Илића“, у Зборник Матице српске за књижевност и језик 29/1: 103134 [Mihailović, D. (1981). "Tri nezavršena pozorišna komada Dragutina Ilića“, u Zbornik Matice srpske za književnost i jezik 29/1: 103-134]

Михаљчић, Р. (1989). Крај српског иарства. Београд: Београдски издавачкографички завод [Mihaljčić, R. (1989). Kraj srpskog carstva. Beograd: Beogradsk i izdavačko-grafički zavod] 
Несторовић, 3. (2004). “Одређени аспекти тумачења драме“, у Ка савременој настави српског језика и книжевности, ур. Љ. Бајић (Београд: Друштво за српски језик и књижевност Србије): 409-419 [Nestorović, Z. (2004). "Одређени аспекти тумачења драме“, у: Ka savremenoj nastavi srpskog jezika i književnosti, ur. Lj. Bajić (Beograd: Društvo za srpski jezik i književnost Srbije): 409-419]

Николић, М. (2012). Методика наставе српског језика и књижевности. Београд: Завод за уџбенике [Nikolić, M. (2012). Metodika nastave srpskog jezika i književnosti. Beograd: Zavod za udžbenike]

Острогорски, Г. (1965). Серска област после Душанове смрти. Београд: Научно дело [Ostrogorski, G. (1965). Serska oblast posle Dušanove smrti. Beograd: Naučno delo]

Петровачки, Љ. (2008). Методичка истраживања у настави српског језика и къижевности. Нови Сад: Филозофски факултет, Одсек за српски језик и лингвистику [Petrovački, Lj. (2008). Metodička istraživanja u nastavi srpskog jezika i književnosti. Novi Sad: Filozofski fakultet, Odsek za srpski jezik i lingvistiku]

Поповић, Р. 3. (1931). Драгутин J. Илијћ: 1858-1926: живот и рад. Београд: Народна штампарија [Popović, R. Z. (1931). Dragutin J. Ilić: 1858-1926: život i rad. Beograd: Narodna štamparija]

Rosandić, D. (1988). Metodika književnog odgoja i obrazovanja. Zagreb: Školska knjiga.

Самарџија, С. (2008). Биографије епских јунака. Београд: Друштво за српски језик и књижевност Србије [Samardžija, S. (1988). Biografije epskih junaka. Beograd: Društvo za srpski jezik i književnost Srbije]

Томић, С. (2015). "Роман о писцу и краљици“, у Роман краљище Наталије, ур. C. Томић (Београд: Службени гласник): 105-119 [Tomić, S. (2015). "Roman o piscu i kraljici", u Roman kraljice Natalije, ur. S. Tomić (Beograd: Službeni glasnik): 105-119]

Туцаковић, С. (2016). “Заснивање проблемског приступа у проучавању драме Јелисавета кнегиња црногорска у настави“, Методички видици 6: 3953 [Tucaković, S. (2016). "Zasnivanje problemskog pristupa u proučavanju drame Jelisaveta kneginja crnogorska u nastavi“", Metodički vidici 6: 39-53]

Фрајнд, М. (1987). "Политика и легенда у српској историјској драми“, у Историјска драма XIX века. Къ. 1, ур. М. Фрајнд (Београд: Нолит): 541 [Frajnd, M. (1987). "Politika i legenda u srpskoj istorijskoj drami“, u Istorijska drama XIX veka. Knj. 1, ur. M. Frajnd (Beograd: Nolit): 5-41]

Фрајнд, М. (1996). Историја у драми, драма у историји: огледи о српској историјској драми. Нови Сад: Прометеј - Стеријино позорје; Београд: Институт за књижевност [Frajnd, M. (1996). Istorija u drami, drama u istoriji: ogledi o srpskoj istorijskoj drami. Novi Sad: Prometej - Sterijino pozorje, Beograd: Institut za književnost] 
Yugoslavia, The Encyclopedia of Science Fiction. Приступљено 20. 3. 2018. URL: $<$ http://www.sf-encyclopedia. com/entry/yugoslavia>

Snežana R. Bulat

Educons University, Sremska Kamenica

Teacher Education Faculty

bulat.snezana@gmail.com

\section{TEACHING INTERPRETATION OF THE DRAMA KING VUKAŠIN WRITTEN BY DRAGUTIN ILIĆ Summary}

It is an undisputable fact that, from a methodical perspective, many of the dramas written by Dragutin Ilić could be observed as aestethicaly relevant in the teaching process. The subject of this paper is the analysis of the historical drama King Vukašin written by Dragutin Ilić. Concrete and precisely designed methodical steps for teaching interpretation of this literary piece are given in this paper. With the teacher's help, students individually determine the cause of the conflicts, analyze those dramatic conflicts and the psychological subtext of the actions and reactions of the drama characters. Ilić's sharp contrast between Vukašin's and Uroš's character traits and life philosophy will be shown on representative examples. Special research attention is devoted to the epic, historical and drama characteristics of the king Vukašin Mrnjavčević. Research has shown that the playwright used traditional poetry and legends, but also authentic historical writings for the creation of this dominant character in his play. On the one hand, in the drama character of king Vukašin we can see the a true epic king - a cunning, ambitious, manipulative usurper and killer of emperor Uroš, but on the other hand we can notice his warrior and governing abilities, courage and fearlessness that portray Ilić's hero much closer to the king's historical figure.

Key words: historical drama, emperor Uroš, king Vukašin, crown, woman.

Примљено: 16. 5. 2018.

Прихваћено: 31. 8. 2018. 